\title{
Does Chinese Vegetable Oil Consumption Have Positive Implications for the Indonesia-China Trade Balance?
}

\author{
Jan Horas Veryady Purba \\ Sekolah Tinggi Ilmu Ekonomi Kesatuan, Bogor, Indonesia \\ janhorasvpurba@gmail.com
}

\begin{abstract}
Indonesia is the world's CPO producer country, and at the same time, Indonesia also the largest exporter of $C P O$ in global market. Some of the main countries that are becoming export destinations for Indonesia CPO are India, China, the European Union, USA and Pakistan. Empirically, it is seen that the phenomenon of widening gap in Chinese vegetable oil consumption patterns, where consumption growth is higher than domestic production growth. This boosted Indonesia's CPO exports to China and subsequently had an impact on the Indonesia-China trade balance. Analytical method used is ordinary least square (OLS), which is arranged in two-equation models. Findings of this study conclude that (a) Indonesia's CPO exports to China are affected by the increase in consumption of vegetable oils in China. This is consistent with the expected hypothesis; $(b)$ the value of Indonesia's CPO exports to China has a positive impact and helps reduce Indonesia's trade balance deficit. This is consistent with the research hypothesis. Indonesia's CPO exports have a positive impact on the IndonesiaChina trade balance, in particular contributing to overcome the Indonesia-China trade balance deficit. This research shows that CPO is Indonesia's strategic commodity that helps overcome Indonesia's trade balance deficit.
\end{abstract}

\section{Article Info}

- Received : September 19, 2019

- Revised : November 28, 2019

- Published : January 16, 2020

- No. Pages : $36-44$

- DOI : 10.33019/ijbe.v4i1.238

- JEL : F14, Q17

- Keywords : consumption pattern, widening gap, trade balance deficit

\section{Introduction}

China has an important role and position in global trade. Currently, the population of China reaches 1.4 billion people, or nearly one-fifth of the world's population (7.2 billion people) (UN, 2016). As the country with the largest population, China is trying to fulfil its domestic consumption and become one of the world's biggest producers of oil. By 2016, China is the world's major producer of soybean oil, with production of 15.58 million tons or $29 \%$ of the world's total production, followed by USA, with production of 10.22 million tons (or 19\%). In the same year, China was also the second-largest producer of rapeseed oil, with production of 6.55 million tons ( $24.6 \%$ of total world production). The world's leading rapeseed producer is the EU-27, with a $36 \%$ share (USDA, 2018).

Although China is a major producer of the world, especially in soybean and rapeseed oil, China is a net importer country, its consumption far exceeds its domestic production. China's soybean 
oil consumption in 2016 reached 16.2 million tons (deficit 613,000 tons), and consumption of rapeseed oil reached 8.2 million tons (deficit 1.65 million tons). Likewise, with other vegetable oil sources, such as sunflower, China also imports 750,000 tons, with total consumption reaching 1.23 million tons, and domestic production only 450,000 tons. (PASPI, 2016). Many world countries are becoming consumers of soybean oil. In global trade, soybean oil is a thin market in the world market (Purba, 2017; Purba \& Sipayung, 2017; PASPI, 2016). In 2016, domestic consumption reached $98.84 \%$ of total production. Exports, imports and re-export activities in global trade reached 11.6 million tons or 21.62 percent of the world's total production. The world's exporters of soybean oil are Argentina and Brazil. Although China and USA are the world's major producers of soybean, only contribute $4 \%$ in the world's soybean market, as well as producer countries as well as domestic consumers.

Unlike the case with CPO, where the volume traded in the world market reached 47.86 million tons or $73 \%$ of production produced by major producing countries. Like Indonesia, total production reached 35 million tons, and domestic consumption of 9.3 million tons, so that $73.5 \%$ of CPO can be exported to global markets. Similarly, Malaysia, with a total production of 21 million tons, Malaysia is able to export 18 million tons $(85.71 \%)$. This is what drives CPO to provide a very large share in global vegetable oil trading. In this context, the most important contribution of CPO in the last two decades, is: "CPO feed the world". Based on the above background, the research question of this study is how is the effect of China's vegetable oil consumption on Indonesia's CPO exports and then how does it imply to overcome the Indonesia-China trade balance deficit? The objectives of this study are to analyze (a) the influence of China's vegetable oil consumption on Indonesia's CPO exports to China, and (b) the effect of Indonesian CPO exports on the reduction of Indonesia-China trade balance deficit.

\section{Literature Review}

Vegetable Oil Consumption is the composite of four major vegetable oil consumption, namely crude palm oil (CPO), soybean oil (SBO), rapeseed oil (RSO) and Sunflower oil (SFO). This pattern is reflected by the consumption percentage of the four sources of vegetable oil (Purba, 2017, Sipayung \& Purba, 2015, Sawit, 2015). Export is the process of transporting goods or commodities from one country to another legally, generally in the process of trading. (Purba \& Magdalena, 2017). Export value is obtained from the multiplication of export volume with the price of the commodity. While imports are trading activities that bring in (goods or services) from abroad (Sukirno, 2015). In this study, the exported commodity is crude palm oil (CPO), while the importing country is China.

Balance of payments is a record of financial flows showing the value of trade transactions and the flow of funds made between a country and another country within a certain period. The balance of payments can be divided into two main parts: current account and capital account balance. A balance sheet containing export and import transactions of goods is called the trade balance. The current account balance records expenditures and receipts (exports and imports) of goods and services together with net transfers. The current transaction provides an overview of the value of transactions resulting from the trade in goods and services (Salvatore, 1990).

Two main factors always affect the current account balance, the exchange rate of the domestic currency against the foreign currency and domestic net income. Changes in real exchange rates constantly affect current transactions, as they reflect the prices of domestic goods and services relative to foreign goods and services. Net domestic income affects the current account through its effect on total domestic consumer spending (Krugman \& Obstfeld, 2005). Exports that are too low will cause the current account balance to be a deficit. 


\section{Research Methods}

This study uses secondary data and categorized as quantitative research. Hypothesis testing is conducted to test the influence of independent variables on the dependent variable. The analytical method used is ordinary least square (OLS) with the following equation model:

$$
\begin{aligned}
& I C P O E=a_{1}+b_{1} C V O C+e_{1} \\
& T B I C=a_{2}+b_{2} \text { VICEC }+e_{2}
\end{aligned}
$$

$\mathrm{ICPOE}=$ Indonesia $\mathrm{CPO}$ Exports (000 tons)

CVOC $=$ Consumption of Vegetable Oil of China (000 tons)

TBIC $=$ Trade Balance of Indonesia-China (000 USD)

VICEC $=$ Value of Indonesian CPO Exports to China (000 USD)

$\mathrm{a}_{1}, \mathrm{a}_{2}=$ constants

$\mathrm{b}_{1}, \mathrm{~b}_{2}=$ regression coefficients

\section{Results}

\section{The Development of Indonesia's Palm Oil Exports to China}

In 2015, Indonesia's CPO exports reached 26.4 million tons. Indonesia's CPO exports to China amounted to 3.99 million tons $(15.22 \%)$ and came in third after India (5.8 million tons or $21.96 \%$ of Indonesia's total CPO exports) and the European Union (4.23 million tons, or $16.03 \%$ ). As Indonesia's palm oil industry grows, Indonesia has become one of the world's major CPO exporters, and even CPO has become one of the world's major vegetable oil sources, where the world's CPO consumption proportion has surpassed the dominance of soybean oil that for decades ranks first in vegetable oil world. This situation puts Indonesia in an increasingly important position in the world market, but on the other hand, the negative campaigns in the trade war on the world vegetable oil market are also increasingly strong in pressuring Indonesia. The superiority of palm that is unbeatable other vegetable oils, especially soybean oil, sunflower oil, rapeseed oil is in terms of productivity and the cheapest price compared to all three.

Indonesian $\mathrm{CPO}$ exports to export destination countries have different characteristics. In the period 2010-2015, Indonesia's CPO exports to China have the largest share proportion but tend to be constant from year to year, which is an average of 5 million tons per year. In the same period, the development of CPO exports to EU countries is in the second position and ranges from 3 to 4 million tons per year. So far, CPO exports to Europe still grow by $1.8 \%$ per year, but the position of CPO exports has begun to feel the pressure from the end consumer side, and the last few years began to decrease around 100,000 tons per year. This is a concern for Indonesia, where the trend of CPO exports to the EU if there are no strong efforts in Indonesian palm oil diplomacy to Europe, it is not impossible, CPO exports to the EU market will continue to decline in the future, and consumers want to develop a source of domestic vegetable oil (rapeseed and sunflower oil), though by paying a higher price. The spirit of nationalism can be implemented with various things, such as palm oil-free, labelling and various other policies.

\section{Pattern of Vegetable Oil Consumption in China}

The pattern of vegetable oil consumption in China shows a very large gap between production and consumption. By 2017, domestic production of all vegetable oils in China reaches 31.8 million tons, while consumption levels have reached 24.2 million tons. This shows the need for exports is quite high, where domestic production is only sufficient 76.2 percent of the 
demand or consumption of vegetable oil in China. The average growth of domestic vegetable oil production in period of 1980-2017 is $9.7 \%$ per year, while consumption grew $10.1 \%$ per year. Thus, the condition that occurs tends to widen (Figure 1). The process of widening gaps between production and consumption of vegetable oils in China began to increase since 2000, in line with the increasing export of CPO on the world market.

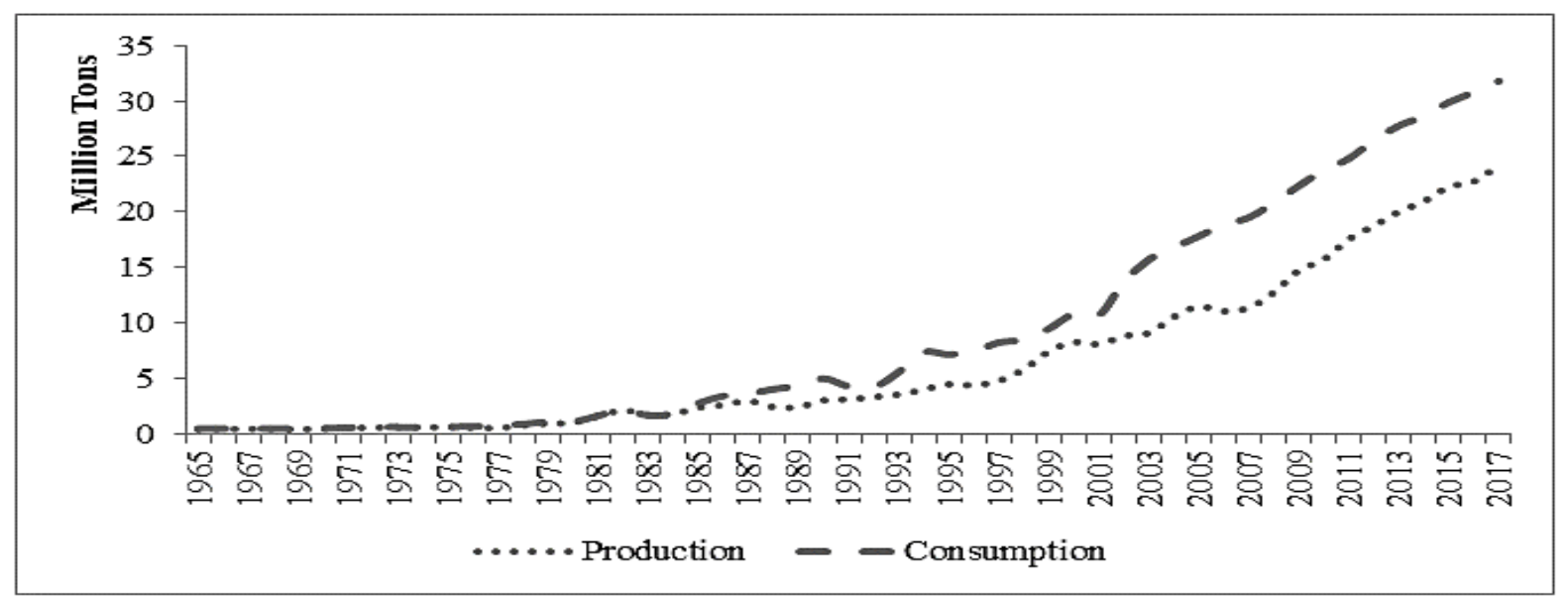

Source: National Agricultural Statistics Service (USDA), 2018

Figure 1. Production and consumption of vegetable oil in China, 1964-2017

Table 1. Average Production, Consumption and Import of Vegetable Oil in China, 1974-2016 (000 tons per year)

\begin{tabular}{ccccc}
\hline Year & Production & Consumption & Import & $\%$ \\
\hline $1974-80$ & 725 & 827 & 108 & 13.1 \\
$1980-85$ & 1787 & 1861 & 119 & 6.4 \\
$1985-99$ & 3885 & 5907 & 2240 & 37.9 \\
$2000-10$ & 11084 & 17352 & 6458 & 37.2 \\
$2011-16$ & 20361 & 28043 & 8207 & 29.3 \\
\hline
\end{tabular}

Source: National Agricultural Statistics Service (USDA)

In 1980, China's average CPO production was still below 1 million tons. But China's domestic consumption has reached 1.97 million tons, and $13.1 \%$ of China's vegetable oil consumption is met by imports. In the 1980-1985 period, the average CPO production of China has reached an average of 1.79 million tons per year, but China's domestic consumption has reached 1.86 million tons, and $6.4 \%$ of China's vegetable oil consumption is met by imports. In the period 1985-1990, China's CPO production has reached an average of 3.9 million tons per year, but China's domestic consumption has reached 5.9 million tons, and the proportion of imports reached $37.9 \%$ of total consumption. This shows that China's vegetable production is only able to meet two-thirds of the total vegetable consumptions. In the period 2000-2010, China's CPO production has reached an average of 11.08 million tons per year, but China's domestic consumption has reached 17.35 million tons. $37 \%$ of China's vegetable oil consumption is met by imports. In 2011-16, China's vegetable consumption increased rapidly, reaching an average of 20.36 million tons, while domestic production reached 28.04 million tons, and the volume of vegetable imports reached an average of about 8 million tons per year.

The data above shows that China's vegetable oil consumption tends to increase every year (growth 9\%/year). The government of China continues to increase domestic production (8.5\%/year). Consumption rate increases at a larger rate, resulting in widening gaps or widening gaps between production and consumption by about $0.5 \%$ per year. This also affects 
the need for imports of vegetable oils with increasing volume every year. Between 1974 and 1980, imports of vegetable oil in China were soybean oil (73\%), and the rest was palm oil (CPO/crude palm oil) of $27 \%$. In the 1980-1985 period, the proportion of CPO imports rose almost 2-fold to $49 \%$ and even surpassed the proportion of imports of SBOs that was $44 \%$, and the rest of the RSO was 6\%. In the period 1986-2000, the proportion of CPO imports has reached half of China's total vegetable imports, while imports of soybean oil/SBO decreased to $33 \%$, while the RSO was 16\%. From 2000 through 2010, the proportion of CPO imports increased and reached $69 \%$, soybean oil/SBO imports decreased by $21 \%$, followed by RSO was 7\% and SFO of 3\%. The last condition shows that between 2011 and 2016, the proportion of CPO imports remained high, at $69 \%$, while the import of soybean oil/SBO was once again reduced by $13 \%$, and the rest came from RSO $11 \%$ and SFO $7 \%$.

The data above shows, during the last 3 decades (1986-2016) the main source of vegetable consumption in China is from CPO imports, while the share of soybean imports decreased. Source of rapeseed oil import (RSO) and sunflower are complementary with share of about 11 and 2\% respectively. This shows a very high demand for CPO imports. In the period 19902016, more than two-thirds of India's vegetable imports, dominated by CPO. In terms of volume, it also appears to increase dramatically, from 1.2 million tons in 1995, to 6 million tons in 2012, and decreased from 2014 to June 2016, but still in large volumes, above 5 million tons per year. On the contrary, soybean oil (SBO) declined sharply, both from volume and share, where 1995 soybean imports reached 1.4 million tons and in 2015 declined sharply to 670,000 tons. RSO tends to grow and fulfil vegetable needs in China. In addition to price factors, rising consumption of vegetable oil in China is also due to rising per capita consumption of China.

Table 2. Average Vegetable Oil Consumption per Capita of China 1975-2016

\begin{tabular}{cccc}
\hline Year & $\begin{array}{c}\text { Consumption } \\
\text { (000 ton) }\end{array}$ & $\begin{array}{c}\text { Population } \\
\text { (million people) }\end{array}$ & $\begin{array}{c}\text { Consumption/capita } \\
\text { (kg/person/year) }\end{array}$ \\
\hline 1975 & 656 & 923.563 & 0,71 \\
1980 & 1.111 & 1.007 .904 & 1,10 \\
1990 & 5.001 & 1.165 .213 & 4,29 \\
2000 & 10.805 & 1.270 .033 & 8,51 \\
2010 & 23.768 & 1.374 .853 & 17,28 \\
2016 & 30.775 & 1.417 .910 & 21,70 \\
\hline
\end{tabular}

Source: PASPI (2016); OECD (2017)

China's vegetable oil consumption in 1975 was $0.71 \mathrm{~kg} /$ person/year, and in 1980 it rose to 1.1 $\mathrm{kg} /$ person/year, and in 1990, China's per capita vegetable consumption reached 4.29 $\mathrm{kg} /$ person/year, and in 2010 it increased sharply to $17.28 \mathrm{~kg} /$ person/year and by 2016 has reached $21.70 \mathrm{~kg} /$ person/year. The per capita consumption data above shows the development of China's vegetable oil per capita consumption with a positive trend, with $6.6 \%$ annual growth.

The results of the data analysis are discussed in the equation below:

$$
\text { ICPOE }=-1041,59+0,287 \text { CVOC }
$$

The findings of this study show that Indonesia's CPO exports to China are influenced by the increase in China's vegetable oil consumption. This is in accordance with the expected hypothesis, in which the CVOC has a positive effect on ICPOE. Hypothesis testing showed significant results at alpha $10 \%$. 


\section{Indonesia-China Trade Balance}

China is one of the important export destination countries of Indonesia. Almost within the last decade, every year Indonesia's trade balance has a deficit with China. According to Statistic Indonesia, known as BPS, throughout 2017, Indonesia recorded a trade balance deficit with China of USD 10.23 billion in September 2017. This deficit is greater than that of Thailand with USD 2.84 billion and Australia USD 2.38 billion. During the cumulative period of January-September 2017, the value of exports to China reached USD 14.57 billion or a percentage of $13.02 \%$. While the value of imports from China reached USD24, 81 billion or $26.07 \%$. This shows the value of Indonesian imports is always higher than the level of exports. Indonesia's Trade Balance with China shows much higher import value than export value (Table 3, Figure 2).

Table 3. Indonesia-China Trade Balance, 2012-2017 (Thousand USD)

\begin{tabular}{ccccccc}
\hline Description & 2012 & 2013 & 2014 & 2015 & 2016 & 2017 \\
\hline Total Trade & 51.045 & 52.451 & 48.230 & 44.457 & 47.591 & 58.817 \\
Migas & 1.219 & 1.599 & 1.310 & 1.972 & 1.784 & 1.982 \\
Non-Migas & 49.826 & 50.852 & 46.921 & 42.485 & 45.808 & 56.834 \\
Export & 21.660 & 22.601 & 17.606 & 15.046 & 16.791 & 23.049 \\
Migas & 795 & 1.320 & 1.147 & 1.786 & 1.673 & 1.727 \\
Non-Migas & 20.864 & 21.282 & 16.459 & 13.261 & 15.118 & 21.322 \\
Import & 29.386 & 29.849 & 30.624 & 29.411 & 30.800 & 35.767 \\
Migas & 424 & 279 & 163 & 186 & 111 & 255 \\
Non-Migas & 28.962 & 29.570 & 30.462 & 29.225 & 30.690 & 35.512 \\
Balance of Trade & $(7.726)$ & $(7.248)$ & $(13.018)$ & $(14.364)$ & $(14.010)$ & $(12.718)$ \\
Migas & 372 & 1.041 & 984 & 1.600 & 1.562 & 1.473 \\
Non-Migas & $(8.098)$ & $(8.289)$ & $(14.002)$ & $(15.964)$ & $(15.571)$ & $(14.190)$ \\
\hline
\end{tabular}

Source: BPS (2016); Ministry of Trade Republic of Indonesia (2017)

Indonesia's exports in 2012 reached USD 21.66 billion and tended to decline from 2013 to 2015 to reach USD 15.05 billion, then increase in the last two years to reach USD 23.05 billion. By comparing Indonesia's non-oil and non-oil exports and imports, the biggest deficit reached USD 14.18 billion by 2015. Although exports increased by USD 8 billion from 2015 to 2017, the impact on the deficit decline was not great, only up to USD 1.72 billion from USD 14.18 billion (2015) to USD 12.46 billion (2017). This is due to the greater volume and import rate compared to exports. However, imports have consistently increased from USD 28.96 billion (2012) to USD 35.51 billion, at a rate of 4.36 percent per year.

The average Indonesian imports from China reached USD 30.74 billion per year, while Indonesia's non-oil exports to China were USD 19.46 billion, and the Indonesia-China trade balance deficit reached USD 11.28 billion per year. This shows that the import/export ratio of Indonesia-China reached 1.576. Indonesia's imports are 57.6 percent higher than Indonesia's exports to China. In simpler language, when Indonesia exported 100, the import reached 157.6 and deficit 57.6. This figure is quite large, and the government's attention to reducing the rate of imports, especially imports of agricultural products or consumable goods consumed. 


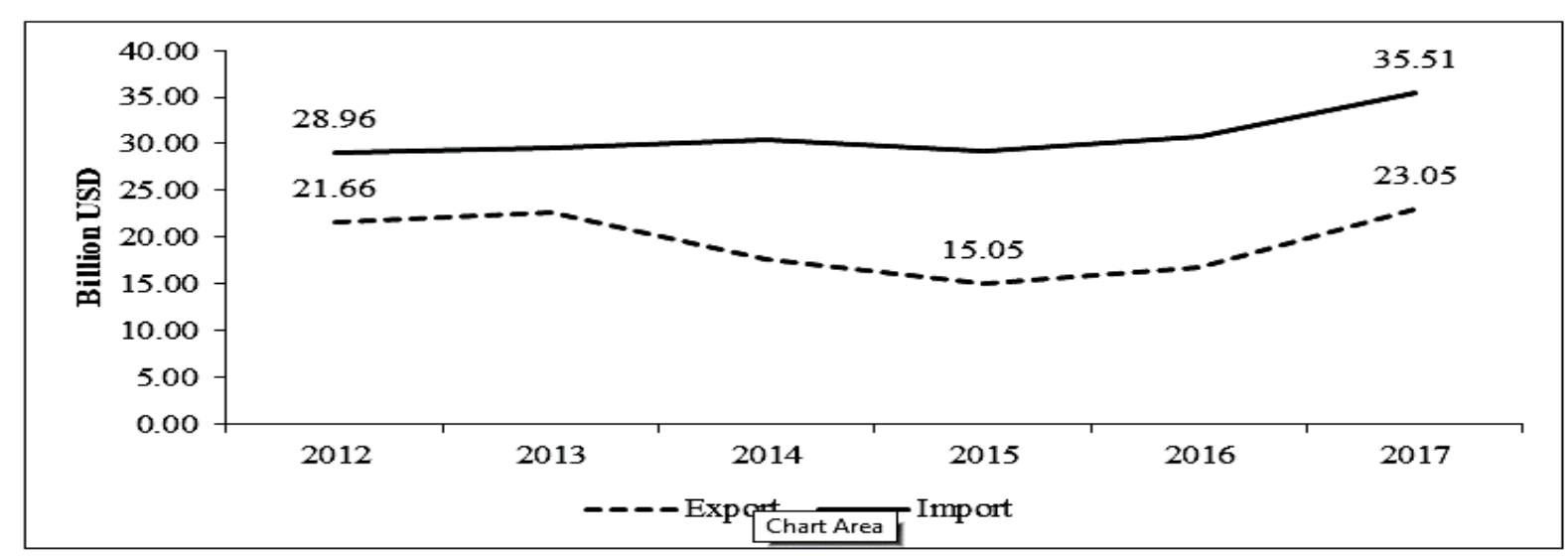

Source: Ministry of Trade Republic of Indonesia (2017)

\section{Figure 2. Exports and Imports of Non-Oil and Gas Indonesia-China, 2012-2017}

\section{Deficit of Trade Balance and Export of CPO}

Deficit in Indonesia-China trade balance has experienced a relatively large volume in the last year. A policy is needed to minimize the deficit in the future. On the other hand, China State is one of Indonesia's CPO export destinations and ranked second only to India. To what extent is the role of CPO exports in helping to deficit the trade balance? The trade balance deficit is shown in Figure 3. Deficit in Indonesia-China trade balance has experienced a relatively large volume in the last year. A policy is needed to minimize the deficit in the future. On the other hand, China State is one of Indonesia's CPO export destinations and ranked second only to India. To what extent is the role of CPO exports in helping to deficit the trade balance? The trade balance deficit is shown in Figure 3.

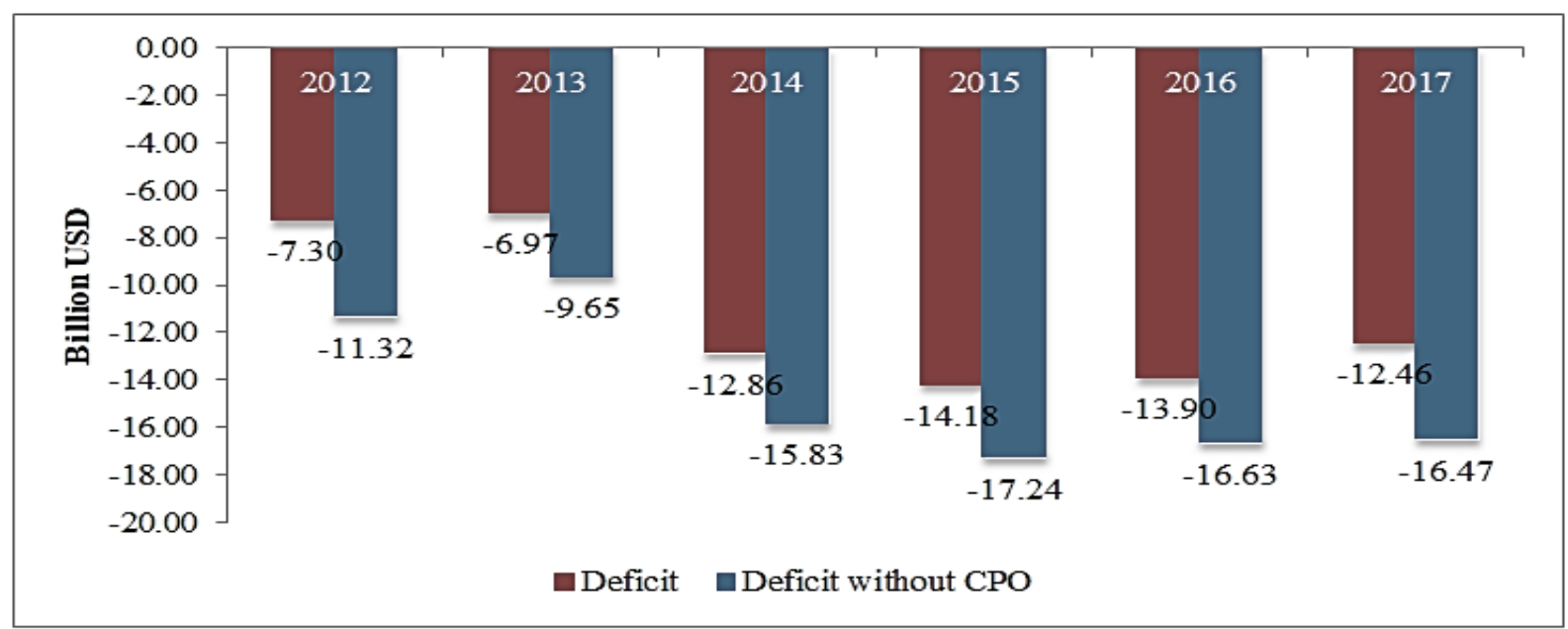

Source: Ministry of Trade Republic of Indonesia (2017)

\section{Figure 3. Trade Balance Deficit and Export Contribution of CPO}

The contribution of CPO exports in reducing the Indonesia-China trade deficit can be seen by comparing the trade balance deficit without Indonesia's CPO exports to China. The average trade deficit in the above period reached USD 11.28 billion. When subtracted by CPO exports, the average deficit in Indonesia-China trade balance reached USD 14.52 billion. Thus, the role of CPO exports is quite large with a contribution of USD 3.25 billion per year. In other words, the contribution of CPO exports in helping Indonesia's trade balance deficit is quite large, at 28.78 percent. 
The results of data analysis are presented in the following equation.

$$
T B I C=9387.356+4.421 \text { VICEC }
$$

VICEC (Value of Indonesian CPO exports to China) has a positive impact on TBIC (trade balance deficit of Indonesia-China). This is following the research hypothesis, where export has a positive effect on the trade balance. By combining the two equations above, the findings of this study are:

1. Increase in Indonesia's CPO exports to China is strongly influenced by China's CPO import demand from Indonesia.

2. Furthermore, Indonesia's CPO exports have a positive impact on the trade balance of Indonesia-China, in particular contributing to overcoming or reducing the deficit of Indonesia-China trade balance.

\section{Conclusion}

When compared to the previous decade, it is seen today that the pattern of vegetable oil consumption in China has changed. There is a tendency to increase imports of large-scale CPO. It also increases the gap between Chinese vegetable oil production and consumption. The production growth rate is $8.5 \%$ per year and less than the $9.0 \%$ annual increase in consumption. In the last three decades (1986-2016), palm oil (CPO) was ranked the largest in China's vegetable import structure and increasingly shifting the share of soybean oil. By 2016, the proportion of CPO imports has reached 69\%, which has tripled in comparison with 1986 share (32\%) while the role of soybean oil has been shifted from 55\% in 1986 to $11 \%$ in 2016 . There is no option for PRC other than importing ever larger CPO, as soybean oil is a thin market in the global vegetable market. The implications of the findings are that (a) the Indonesian palm oil industry has an important role in the acquisition of foreign exchange for Indonesia, (b) Indonesia's CPO exports have a considerable contribution in assisting Indonesia-China trade balance deficits.

Despite the apparent excess demand in Chinese vegetable oil consumption, the proportion of Indonesia's CPO exports is still relatively low but has opportunities to be increased. Therefore, the position of China must be seen as a strategic trading partner and a positive campaign for palm oil is still needed in the future. Also, further research suggestions are more in-depth research on soybean oil consumption in China, because China is a producer and consumer of global soybean oil.

\section{References}

1) BPS (Statistic Indonesia). (2016). Statistik Kelapa Sawit Indonesia. Jakarta: BPS.

2) Ministry of Trade Republic of Indonesia. (2017). Ekspor-Impor 2013-2017. Jakarta: Kementerian Perdagangan RI.

3) Krugman, P. R., \& Obstfeld, M. (2005). Ekonomi Internasional : Teori dan Kebijakan. Jakarta: PT Indeks.

4) OECD. (2017). Agricultural Outlook. Retrieved from http://www.ers.usda.gov/ publications/AgOutlook/Jan2002/ 81

5) PASPI. (2016). Konsumsi Minyak Nabati China Dan Dampaknya Bagi Ekspor CPO Indonesia. Monitor, Strategic Analysis of Palm Oil, 2(43), 560-566.

6) Purba, J. H. V. (2017). The analysis of European Union's vegetable oil consumption: "will the 
IJBE (Integrated Journal of Business and Economics) e-ISSN: 2549-3280/p-ISSN: 2549-5933

European Parliament Resolution Halt the Consumption of Crude Palm Oil in the European Union in the future?" International Journal of Applied Business and Economic Research, 15(19).

7) Purba, J. H. V., \& Magdalena, A. (2017). Pengaruh Nilai Tukar terhadap Ekspor dan Dampaknya terhadap Pertumbuhan Ekonomi Indonesia. DeReMa Jurnal Manajemen, 12(2), 285-295.

8) Salvatore, D. (1990). International Economics 3rd edition. Singapore: MacMillan International Edition.

9) Sawit. (2015). Sawit Indonesia. Retrieved from https://sawitindonesia.com/kontribusi-kelapasawit-sebagai-pilar-perekonomian-bangsa/

10) Sipayung, T., \& Purba, J. H. V. (2015). Ekonomi Agribisnis Minyak Sawit. Bogor: Kesatuan Press.

11) Sukirno, S. (2015). Makroekonomi. Jakarta: Rajawali Press.

12) USDA. (2018). Index Mundi. United State Department of Agriculture. 